\title{
Assessing the Impact of Electronic Business on the Performance of Small and Medium-Sized Businesses in Kumasi, Ghana
}

\author{
Emmanuel Oppong-Mensah ${ }^{1 *}$, S. P. Sreekala ${ }^{2}$, Gabriel Dwomoh ${ }^{3}$, Henrietta Oppong- \\ Dwamena $^{4}$ \\ ${ }^{1,2}$ Texila American University, Ghana \\ ${ }^{3}$ Kumasi Technical University, Ghana \\ ${ }^{4}$ University of Turin, Italy
}

\begin{abstract}
The study evaluated how electronic business impacted the performance of a selected small and medium-sized enterprises (SMEs) in Kumasi. A convenient sample of 50 SMEs in wholesale and retail of consumer goods in Kumasi were selected at random to be surveyed; however, only 30 responded. Structured questionnaires were used to collect quantitative data from the participants to answer the research questions. The results were statistically analyzed to draw conclusions. The results revealed that, to a large extent, the businesses used e-business methods in several ways to undertake five categories of business activities which include advertising, customer support service, marketing, payment system, and order and delivery. Several factors influenced the adoption and use of e-business methods by the businesses, but the most influencing ones were the businesses' customers' low use of ebusiness and telecommunications services not being very dependable. It was also discovered that the adoption and use of e-business made positive impact on the businesses' performance. It is therefore recommended that more SMEs be encouraged and assisted to fully embrace the use of e-business.
\end{abstract}

Keywords: Assessing, Electronic Business, Impact, Performance.

\section{Introduction}

\section{Background to the Study}

Today's business has taken a new trend due to advancements in technology. Traditional methods of conducting business are being replaced daily by more modern and sophisticated ones which make business faster and easy to do.

In other words, the emergence and growth of the internet has brought several changes in the way businesses and countries conduct business and exchange information among themselves. The electronic business, also referred to as electronic commerce, is one of the products of the development of the internet. Electronic business or e-commerce is referred to as "the sharing of business information, maintaining business relationships, and conducting business transactions by means of telecommunications networks" [1]. This includes an exchange between businesses (B2B), between customers (C2C), between businesses and customers (B2C), and between government and businesses (G2B) [2].

It is widely claimed that doing business by electronic means has several advantages over the traditional methods of doing business. It is generally believed that the application of ebusiness and management information systems has led to improved information exchange with customers/suppliers, improved customer service, expanded business reach, access to international markets, and reducing costs [3, 4]. As Moodley observed, business-to-business in 
e-commerce holds great promise for firms, especially in terms of collaborating with suppliers; enhancing supply chain management by reducing overall inventory levels, transportation costs and order and delivery lead times; and increasing the speed and efficiency of economic transactions [5].

In spite of the several benefits of e-business and management information systems (MIS), it is not every business, especially in developing countries, including Ghana, adopts and uses ebusiness and MIS due to several factors. There is a generally slow pace of information technology development in developing countries, affecting the adoption rate and use of e-business. Other factors affect the rate at which small and medium scale enterprises adopt ebusiness and MIS, which are worth investigating in order to find solutions to them.

Moreover, small and medium enterprises (SMEs) are known to be the backbone of economic development in developing countries. They are considered as essential for delivering more inclusive globalization and growth, and SMEs make diverse contributions to economic and social wellbeing, which could be further enhanced [6]. In Ghana, several studies have shown that SMEs account for 92\% of all businesses in the country and contribute about $70 \%$ of Gross Domestic Product [7, 8, 9]. It is, therefore, necessary for SMEs to be encouraged and assisted in adopting and using e-business and MIS methods to help enhance their performance.

It is against this background that this study sought to assess the impact of electronic business on the performance of selected small and medium-sized (SMEs) in Kumasi.

\section{Statement of the Problem}

According to several studies, many SMEs experience low growth and collapse in some cases due to poor methods of conducting business $[8,10,11]$. Failing to use modern and sophisticated electronic methods of business does not help the growth and development of businesses in developing countries.

Some amount of studies has been conducted into the adoption and use of e-business methods among SMEs in Ghana, for example [12, 13, 14, $15,16,17,18]$. These studies agree that the adoption and usage of e-commerce among small businesses in Ghana is not without challenges. Their findings indicate that several cultural, technical, and economic factors impede the effective adoption and use of e-commerce including lack of technical know-how or limited knowledge of e-commerce models and methodologies, low use of e-commerce by customers and suppliers, concerns about security aspects, concerns about legal and liability aspects, ease of use, frequent power disruption, and lack conviction about the benefits of ecommerce.

However, e-business and MIS continue to experience change through technological advancement. It is, therefore, necessary to investigate how SMEs in Ghana, a developing country, are coping with the fast-developing business world. Moreover, there is not enough empirical evidence on the impact of electronic business adoption on the performance of SMEs in Kumasi in particular. Therefore, this study seeks to investigate and analyze the impact of ebusiness and MIS usage on the performance of selected SMEs in Kumasi. It focuses on analyzing whether there is a significant relationship between e-business and MIS usage and the operational, marketing, and financial performance of these businesses in Kumasi.

\section{Objectives of the Study}

The aim of the study is to assess the impact of electronic commerce on the performance of selected small and medium-sized enterprises in Kumasi who are into wholesale and retail of consumer goods. The study seeks to achieve these specific objectives: 
1. To examine the nature and extent of adoption and usage of e-business and MIS methods by SMEs in Kumasi.

2. To find out factors that influence the adoption and use of e-business and MIS by SMEs in Kumasi.

3. To assess the relationship between ebusiness and the performance of SMEs in Kumasi.

\section{Research Questions}

The following questions are addressed by the study:

1. What is the nature and extent of adoption and usage of e-business and MIS methods by SMEs in Kumasi?

2. What factors influence the adoption and use of e-business and MIS by SMEs in Kumasi?

3. What is the relationship between e-business and the performance of SMEs in Kumasi?

\section{Scope of the Study}

The study was conducted in Kumasi, which is the commercial and regional capital of the Ashanti Region of Ghana. The study was limited to a few small and medium enterprises in the central business area of the city, Adum. The study focused on issues limited to operational, market, and financial performance of the selected SMEs with reference to their use of ebusiness and MIS in marketing, advertising, and exchange of information.

\section{Review of Literature}

\section{Meaning of Electronic Business}

Electronic business (also referred to as ecommerce) is an important business method. The most popular definition of e-business is by Zwass, who defines e-commerce as the sharing of business information, maintaining business relationships, and conducting business transactions by means of telecommunications networks [1].

The terms "e-commerce" and "e-business" are often used interchangeably, both of which apply to aspects of doing business using the
Internet. However, some distinguish between the two terms by using "e-commerce" to refer to business-to-consumer (B2C) business transactions, while using "e-business" to refer to business-to-business (B2B) transactions, as well as internal organizational use of the Internet for business operations such as intranets [19].

In a nutshell, e-business in the context of this study is all aspects of doing business using the Internet, including business-to-consumer (B2C) business transactions and business-to-business (B2B) transactions, as well as internal organizational use of the Internet for business operations such as intranets.

\section{Performance}

There are several definitions of performance in the literature of organizational studies, but generally, it comprises the actual results or output of an organization as measured against its intended results or outputs.

It is argued that organizational performance is probably the most widely used dependent variable in organizational research today, yet at the same time, it remains one of the vaguest and loosely defined constructs [20]. Measuring organizational performance is difficult, especially when what has to be measured keeps changing [21]. Typically, there are different ways to characterize various types of organizational performance in small and medium-sized enterprises. Dyer and Reeves proposed four possible types of measurement for organizational performance in small and medium-sized manufacturing firms: 1) Human resource outcomes (job satisfaction, absenteeism, turnover), 2) Organizational outcomes (quality, productivity, service), 3) Financial accounting outcomes (return on assets, profitability) and 4) Capital market outcomes, (stock price, growth, returns) [22]. 
Pierre argued that organizational performance encompasses three specific areas of firm outcomes: (a) Financial performance (profits, return on assets, return on investment, etc.); (b) Product market performance (sales, market share, etc.); and (c) Shareholder return (total shareholder return, economic value-added, etc.) [23].

According to the literature review, the most common types of organizational performance measures that are used in recent empirical researches are financial or accounting performance, operational performance, and market-based performance $[24,25,26,27,28$, 29].

In the context of this study, performance is defined as the achievement of the goals and objectives of the business, including operational goals and objectives, which refers to expected market share, introduction and promotion of new product/service, product/service quality, marketing effectiveness, and customer satisfaction. Market performance refers to return to shareholders, market value-added, and annual return. Financial and accounting performance refers to profitability, financial growth, leverage, liquidity and cash flow, accounting efficiency.

\section{Phases of E-business Adoption}

E-business embraces several forms of transactions which include information exchange between businesses (B2B), between customers (C2C), between businesses and customers (B2C), and between government and businesses (G2B) [2]. It is observed that firms take different paths in adopting and integrating e-commerce in their business operations [30, 31] in their Perceived Readiness Model (PERM Model), present a hierarchical model of the functional application of the Internet by firms to create business value. The hierarchical phases of e-commerce adoption, according to [31], are no e-commerce, connected e-commerce, static ecommerce, interactive e-commerce, and transactive e-commerce.
The model has been subsequently used in other studies [32, 33, 34, 35]. As explained by [31] and [30], the adoption phases enable the firms with the following e-commerce capabilities.

\section{Adoption and Use of Electronic Business Methods by SMEs in Developing Countries}

It has been the concern of researchers and policy-makers to examine the use of ecommerce among small and medium-sized enterprises in developing countries. Thus, several studies have been conducted that reveal the extent of adoption and use of e-commerce among SMEs in developing countries [36, 37, $38,39,17]$. The results of these studies are several depending on the countries and business sectors in which they were conducted. Generally, the adoption and use have not been rapid and massive due to several challenging factors. However, it has been improving over the years.

According to Cloete and Courtney, small businesses' acceptance and adoption of ecommerce in the Western-Cape Province of South Africa. A secondary aim of the study was to determine the level of e-commerce adoption by small manufacturing businesses in the Western Cape. The results of the study indicated that the majority of small manufacturing businesses had not adopted e-commerce activities into their businesses. However, it was found that most of these businesses had plans to implement e-commerce activities within the next three years from the period of the study [40].

Moodley explored the state and likely future direction of business-to-business (B2B) ecommerce in the South African manufacturing sector. The study results suggested that $\mathrm{B} 2 \mathrm{~B}$ ecommerce was in an embryonic stage in the South African manufacturing sector, and technology and market dynamics were still casting their basic shape [5]. He observed that the ability to realize efficiency gains in the B2B electronic marketplace would largely hinge on 
the climate of confidence and trust businesses could create in their relations with their suppliers and customers.

[38] carried out a survey to find the nature and extent of e-commerce adoption by tourism organizations from South Africa, Kenya, Zimbabwe, and Uganda, which are all popular tourist destinations in eastern and southern Africa. For comparison, the second survey of tourism organizations from USA and Western Europe was also carried out by [38] in which a total of 373 websites from the four African countries and 180 from the USA and Western Europe were accessed and then evaluated against a list of e-commerce features. The results of the study revealed that few of the African organisations were embracing e-commerce and that, although some websites were comparable to those of their western counterparts, the majority had room for considerable improvements. The African websites were found to be generally informative but lacked interactive facilities for online transactions.

[39] examined the commitment of top management to e-business development in Ghanaian tourist firms by surveying 60 tourism firms. The study results revealed that despite the fact that e-business holds the promise of delivering benefits to Ghana tourism firms, their understanding of e-business/ICT still remained at an operational level.

Similarly, [17] found that many SMEs in Kumasi, Ghana, had not fully adopted ecommerce solutions. The results of his study showed that SMEs online sales was virtually nil, that the most common e-commerce application was the use of e-mail for communication, and the main reason for having a website was to show basic information about product and services as well as contact information.

\section{Benefits of Electronic Business on the Performance of Businesses}

Research has shown that e-commerce holds numerous benefits for businesses that adopt and use it properly. [41] found that perceived benefit was a key reason organisation adopted and continued to use the Internet. They classified perceived benefits into 'direct' and 'indirect' benefits. Direct benefits are quantifiable by using techniques such as data analysis and measuring variables such as the number of new customers as a result of e-commerce implementation. Indirect benefits are not easily measured but rather have a positional effect on the business, e.g., customer loyalty and goodwill as a result of added value and services provided online [40].

[41] also identified short-term and long-term benefits. Short-term benefits should be realized within months, whereas long-term benefits may take longer to be achieved and are unpredictable. Their research showed that SMEs were reaping insignificant, marginal short-term benefits from e-commerce. They identified long-term benefits as being the key motive for ongoing Internet activities and that these might include additional customer enquiry, forming new networks, and reaching previously untapped markets.

In a nutshell, the benefits of e-commerce include improved information exchange with customers/suppliers, improved customer service, expanded business reach, access to international markets, and reducing costs $[3,4]$.

\section{Factors Determining the Adoption and Use of Electronic Business among Small Businesses in Developing Countries}

Several factors influence the adoption and use of e-commerce. These factors are useful in determining why an SME is at a certain level regarding the adoption and use of e-commerce in their business. Such factors have been identified to include business owner's characteristics, the organization's characteristics, and contextual characteristics [42]:

\section{Owner's Characteristics}

The acceptance of e-commerce by the business owner themselves is a determining factor for adopting and using e-commerce in the business. This means that where an owner does 
not perceive the e-commerce technology as useful or understand its potential, they will be reluctant to adopt it [4].

The level of computer literacy of the owner and a lack of knowledge on how to use the technology will result in the business being less likely to adopt e-commerce [43]. [44] found that level of assertiveness and rationality of the owner in decision making would make the owner more likely to adopt the use of ecommerce if it suited the organisation.

If the owner is subjective and refers to the opinions of experienced people who recommend the adoption of e-commerce into the organisation, then he is also more likely to accept their opinions [3]. SME owners are also concerned with return on investment. The pressure to show a return often leads to small firms being more concerned with medium-term survival rather than long-term viability [45]. As a result, owners are often hesitant to make substantial investments when short-term returns are not guaranteed.

\section{Organization's Characteristics}

The organization itself is also another important determining factor for e-commerce adoption. The amount of technology currently in use in the organization, such as PCs with modems and email facilities, can ease adoption [4]. Adoption has also been found to be largely dependent on external pressure from the business' competitors as well as its supply chain [47]. Businesses might adopt e-commerce as a result of their competitors using it so as not to lose their competitive advantage. If an organisation has large amounts of data and transactions, then it is more likely to adopt IT, which can help streamline operations and offer process efficiencies within the organisation [48].

In their research on small businesses, [45] found two factors affecting IT adoption that had previously not been recognized. The first was mistrust of the IT industry, as some owners perceived the IT industry to be 'over-selling the benefits of technologies and misinforming them.
The second factor was a lack of time to get acquainted with the opportunities and challenges of the Internet due to its quick evolution rate.

\section{Contextual Characteristics}

The economic benefits of moving business transactions from fax, telephone and post to the Internet are well documented in many publications [49]. [50] also noted that the forces of economic rationalism and globalism have enhanced the market as the final arbiter of price and service with the balance of power tilting from the manufacturer towards the consumer. Given this erosion of margins, companies need to reduce costs, both in production and transaction, in order to make their products and services more competitive. This again points to the Internet as a vehicle to reduce costs and to assist in obtaining a competitive advantage in the short term.

The traditional value chain has become virtualized to a great extent due to the fact that users of the Internet are able to order products and services online, without the intervention of the purchasing department, while the payment is made electronically using electronic funds or purchase cards. The primary activities in the Porter Value Chain, namely incoming logistics, outgoing logistics, marketing, and sales, are being redefined in terms of how they are carried out and interact with each other, as technology provides for more sophisticated methods of business interactions [51].

Researchers have further identified a number of additional issues that impact the adoption of e-commerce. These are summarized by [42] as low use of e-commerce by Customers and Suppliers (i.e., there is little incentive for SMEs to engage e-commerce until their customers and suppliers are also using it); concerns about security aspects; concerns about legal and liability aspects; high costs of development and computer and networking technologies commerce; limited knowledge of e-commerce models and methodologies; unconvinced of benefits to the company. 
In his examination of business-to-business ecommerce in the South African manufacturing sector, Moodley [5] found that the major constraints that confronted the sector with regard to adopting e-commerce were the slow pace of planned liberalisation of the telecommunications sector, problems with the consolidation of technical standards, unexpectedly high implementation costs, high cost of broadband connectivity, and inadequate e-commerce infrastructures, skills, and capabilities.

[52] examined the relationship between the perceptions of the strategic value of e-commerce and e-commerce adoption among 107 owners/managers of small and medium-sized enterprises (SMEs) in Ghana as a transitional economy. Their study found that organizational support was the strongest predictor on the perceived strategic value (PSV) construct, followed by managerial productivity and decision aids. Perceived usefulness, compatibility, external pressure, and organizational pressure were found to be statistically significant determinants of ecommerce adoption. Additionally, it was found that ease of use was also influential in the ecommerce adoption decision of Ghanaian SMEs. [53] showed that, in order to understand the adoption and diffusion of e-commerce in developing countries, cultural issues need to be considered.

[54] examined the factors that affected Internet and E-commerce adoption among small exporting handicraft firms in Ghana. Their findings indicated that the internal factors that affected internet and e-commerce adoption of the firms were perceived benefits of the technology from owner/manager characteristics, lack of qualified staff to develop and support ecommerce website from firm characteristics, and limited resources from cost and return on investment. The key external factors affecting the adoption, according to [54], included limited Internet Service Providers (ISP), lack of online payment process, pricing structures, and limited availability of online banking services, power failure, and low competition in the industry.

[55] found that SMEs in Botswana and Ghana were faced with myriad challenges in the adoption of ICT and thus e-commerce. Comparing Botswana and Ghana, [55] discovered that both Botswana and Ghana shared a number of challenges regarding the adoption of ICT, but also there were a number of differences in the way SMEs in these developing countries perceived their problems. For instance, both agreed that frequent power disruption was a hindrance to SMEs in their adoption of ICT, but that SMEs did not consider lack of technical know-how to be a hindrance.

[17] examined e-commerce adoption in Ghana and discovered that the barriers to ecommerce adoption included: lack of right technical skills, e-commerce security, initial cost, resistance by people and culture, lack of interest by management, lack of developed legal and regulatory system.

[56] focused on identifying the major determining factors in Ghanaian SMEs' ecommerce adoption. The results of their study indicated that government support had the greatest direct impact on intentions to use ecommerce. Managerial support and the influence of enabling and regulatory conditions also played a vital role in stimulating SME ecommerce adoption in Ghana. The results also showed that Ghanaian SMEs tend to imitate successful first-movers to avoid the risks that attend e-commerce technology.

Based on survey data from 150 businesses in South Africa, [31] found that initial e-commerce adoption was explained more by perceived organizational e-readiness (POER) than by perceived environmental e-readiness (PEER), but PEER factors and POER commitment and governance variables explain the extent of institutionalization of e-commerce. The results of the study indicated that firms in developing countries should pay attention to both organizational and environmental considerations 
when making e-commerce adoption decisions. They also implied that investment in infrastructure development by governments and other agencies should go hand-in-hand with schemes for business development and managerial improvement at the organizational level.

\section{Methodology}

\section{Research Design and Approach}

The study adopted the explanatory research design which is "conducted to identify the relationships among variables when the research problem has already been narrowly defined" [57]. Also, the case study approach was adopted to investigate the adoption and use of ecommerce among the selected SMEs in Kumasi.

A case study is "an experimental enquiry that examines a modern phenomenon within its reallife context, especially when the borders between phenomenon and context are not obviously evident and it relies on multiple sources of evidence" [58]. The case study is commonly applied in field-based research to describe and develop knowledge that are based on data from real-world conditions, aiming to bridge the gap between theory and practice [59, 58]. The case study method permits the generalization of the findings [59].

Also, the quantitative method of data collection and analysis was employed to achieve the objectives of the study. The quantitative research method uses numbers and statistical methods to explain and analyze phenomenon, events, and views as well as presenting results using tables, diagrams and other statistical tools [59]. The quantitative approach allows the researcher to use a structured questionnaire survey [59].

\section{Population}

A population is "a complete group of entities sharing some common set of characteristics" [57], and the population of relevance or target population is "the specific, complete group relevant to the research project" [57]. The target population for this study consisted of small and medium-sized enterprises in wholesale and retail of consumer goods at Adum, the central business area of the Kumasi Metropolis.

\section{Sampling Technique and Sample Size}

As [60] rightly observed, "researchers cannot study everyone everywhere doing everything." [61] further iterates the idea by explaining that a sample is a sub-group of the population which is an ideal representative of the entire population.

There are several thousands of SMEs in Kumasi; however, only a convenient sample of 50 enterprises were selected at random to participate in this study. The simple random probability sampling technique, which gave each SME an equal chance to be selected, was used to select the 50 participants for the study. However, only 31 out of the 50 selected enterprises responded.

\section{Methods of Data Collection}

The study made use of both primary and secondary data. Primary data was collected through structured questionnaires administered to gather the views and facts about the SMEs used of e-business and MIS. Questionnaires are survey instruments that aid in the collection of quantitative data from a large number of respondents.

The questionnaire used had two sections - A and B. Section A was used to collect data about the profile of the businesses. Section B of the questionnaire was used to collect data relating to the e-commerce use and performance of the businesses. It had items that have been categorized into operational performance, financial performance, and market-based performance. The items require the respondents to choose one answer out of five alternatives. The scale used is the Likert scales, where the five alternatives are not at all, very little, some extent, large extent, and very large extent.

On the other hand, secondary data was sourced through online and printed journals, books, and other relevant printed documents and 
used to provide theoretical and conceptual support for the study.

\section{Data Analysis}

Data analysis is "the application of reasoning to understand and interpret the data that have been collected" [57]. The quantitative method of data analysis was used to analyze the data. Descriptive statistics included frequencies, percentages, mean and standard deviations of the responses relating to the adoption and use of ecommerce and performance. The results are presented using tables and charts.

\section{Results and Discussion}

\section{Background of the Selected Businesses}

Data on the background of the selected businesses were first collected and analysed. Background information that was relevant to the study includes business type by ownership, type of business by sales, business size, and level of computer literacy of the owners. Details of these are presented as follows:

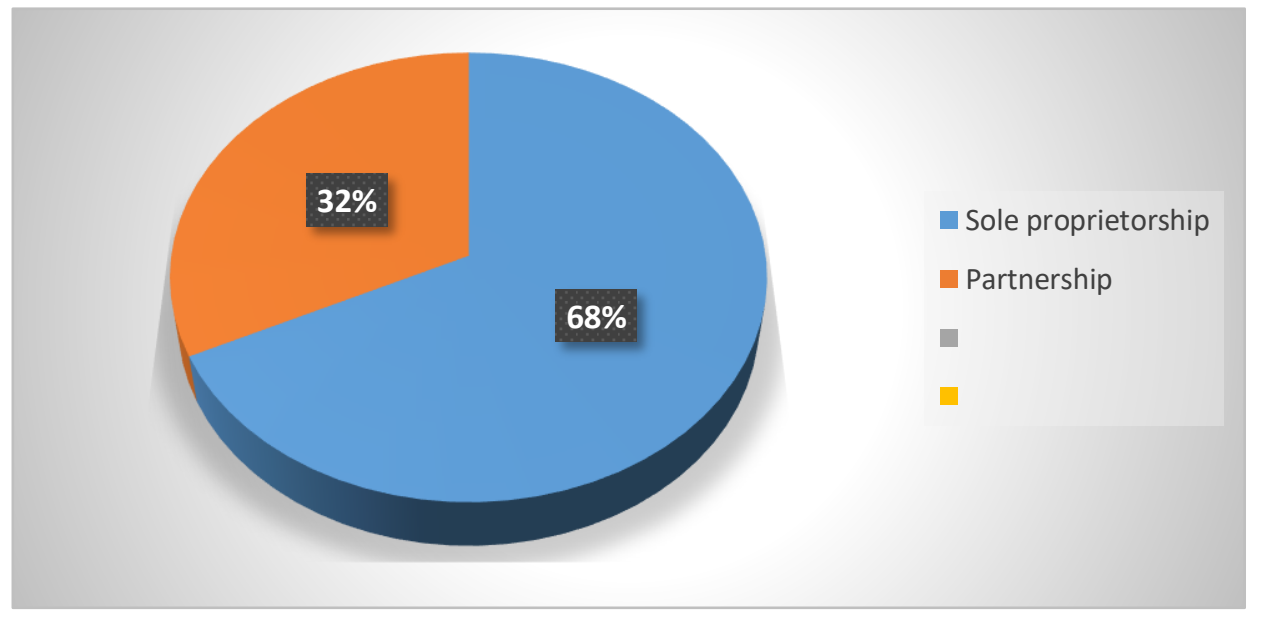

Figure 1. Business Type by Ownership

Figure 1 shows that the majority $(67.83 \%)$ of the businesses that responded were sole proprietorships by ownership. This means that they were the type of businesses owned controlled by one person. These types of businesses are known to be predominant among all SMEs in Kumasi.

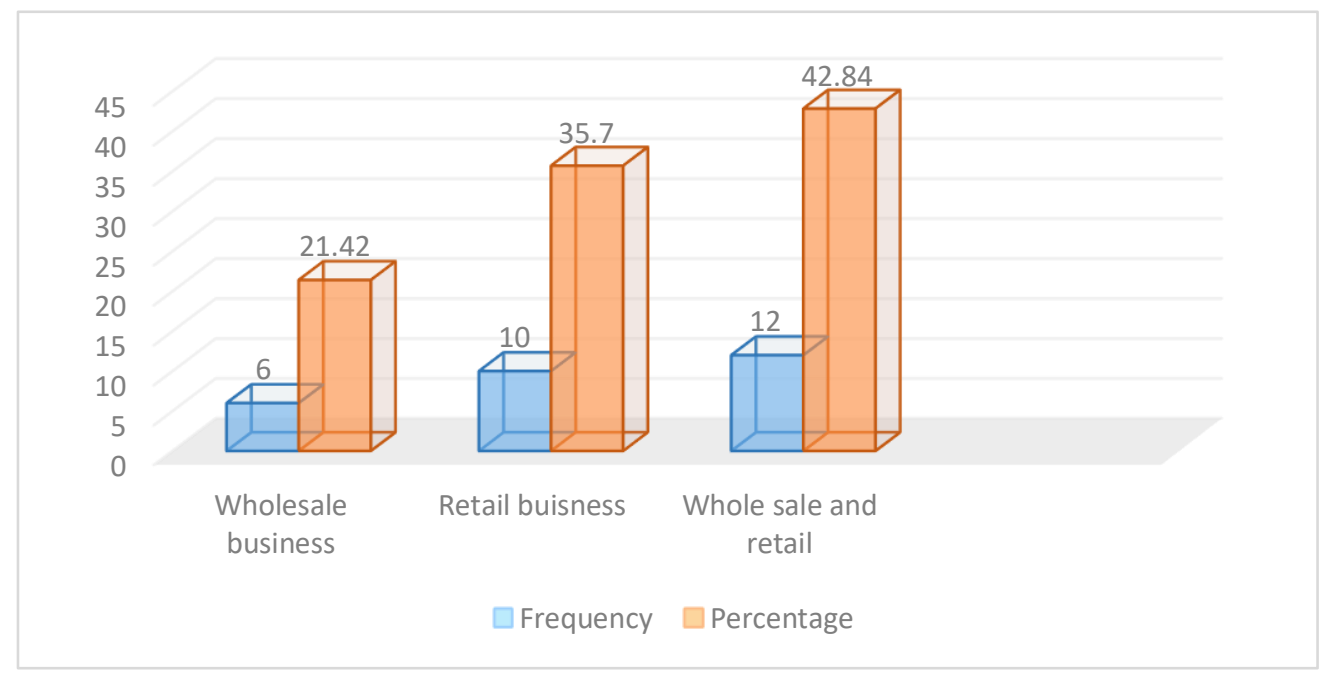

Figure 2. Business by Type of Sale

Source: Field Data, 2020 
With regard to business by type of sales, it was discovered that businesses that both sold on wholesale and retail formed the majority of the businesses that responded to the study. They made up $42.84 \%$ of the total. This was followed by the businesses that were into retail only.

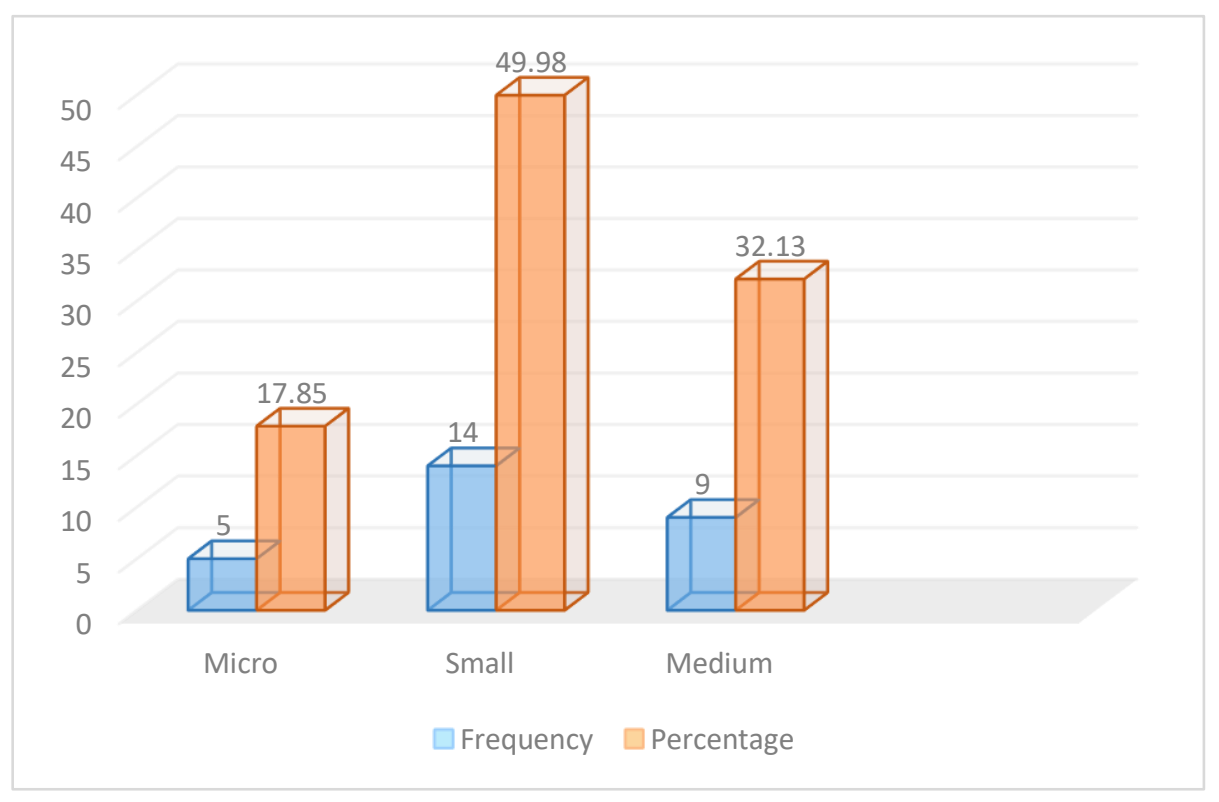

Figure 3. Type of Business by Size

By size, the businesses were categorized into micro, small, and medium-size by a number of employees and assets size. According to NBSSI Ghana (1998), micro-enterprises are those that employ up to 5 employees with fixed assets (excluding land and building) not exceeding the value of $\$ 10,000$; small enterprises employ between 6 and 29 employees or having fixed assets (excluding land and building) not exceeding $\$ 100,000$, and medium enterprises employ between 30 and 99 employees with fixed assets of up to $\$ 1 \mathrm{~m}$.

Figure 3 above shows that of the 28 businesses that responded, the majority $(49.98 \%)$ were small-sized enterprises employing between 6 and 29 employees. The least was micro-enterprises which made up just $17.85 \%$ of the total.

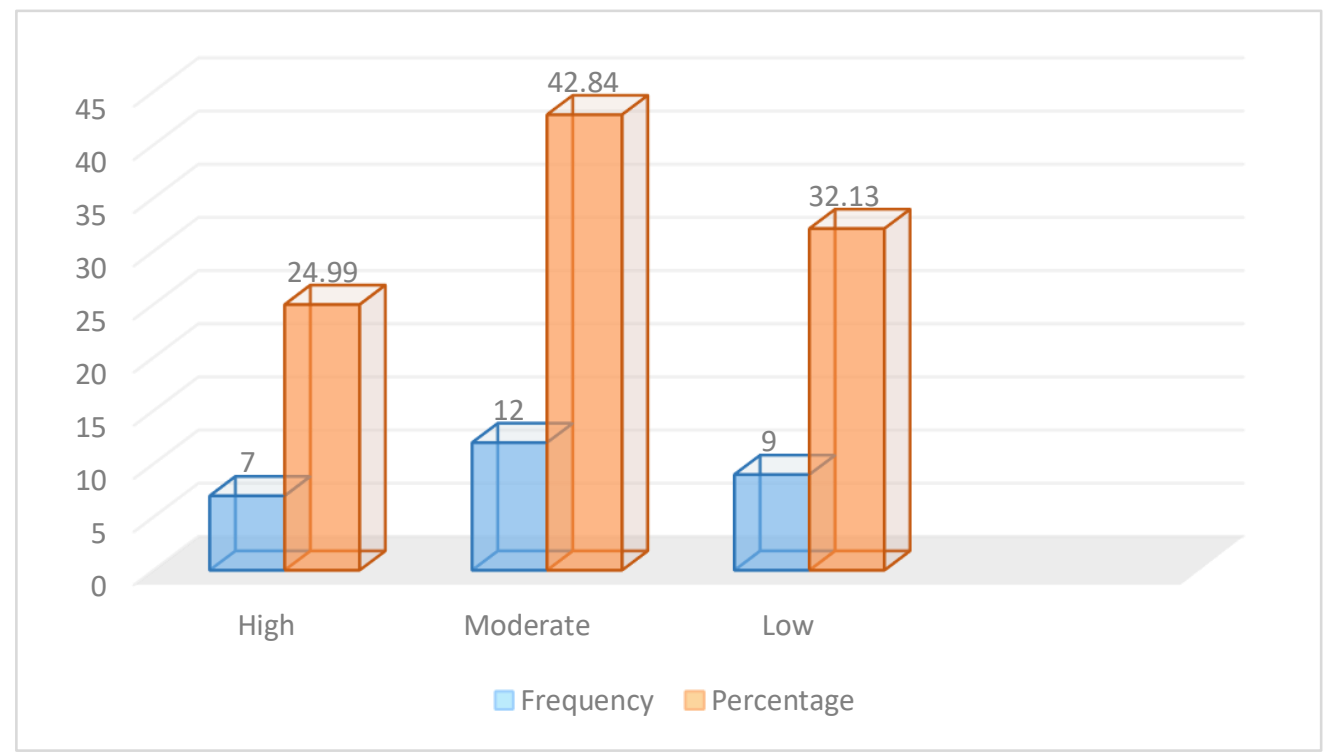

Figure 4. Level of Business Owner's Computer Literacy 
Finally, the level of computer literacy of the owners of the businesses that responded was of relevance to the study as this is considered a critical factor in the success of e-business adoption and usage by SMEs. It was realized that the percentage of the owners whose computer literacy was low was lower than those whose knowledge was moderate. This means that majority of the owners had appreciable knowledge and skills in using the computer to do business. This was good for the businesses since previous studies show that business owners with considerable knowledge and skills in computing often embrace and use e-business methods than their counterparts who do not.

\section{Nature and Extent of Adoption and Usage of E-business by}

On a scale of 1 to 5 representing " $1=$ not at all, $2=$ very little, $3=$ some extent, $4=$ large extent and, $5=$ very large extent", the respondents were asked to indicate the extent to which their businesses used telecommunication networks and internet to undertake a list of advertising, customer support service, and marketing activities. Table 1 below presents a summary of their responses:

Table 1. Summary of the Nature and Extent of the Adoption and Usage of e-business

\begin{tabular}{|l|l|l|l|l|l|}
\hline & $\mathbf{N}$ & Minimum & Maximum & Mean & $\begin{array}{l}\text { Std. } \\
\text { Deviation }\end{array}$ \\
\hline Online products updates & 28 & 3 & 5 & 4.37 & 0.630 \\
\hline Electronic fund transfer (EFT) & 28 & 3 & 5 & 4.26 & 0.719 \\
\hline Online credit card processing & 28 & 2 & 5 & 4.20 & 0.865 \\
\hline Share information with competitors & 28 & 3 & 5 & 4.16 & 0.526 \\
\hline Making payments to suppliers online & 28 & 3 & 5 & 4.15 & 0.730 \\
\hline Coordinating procurement with suppliers online & 28 & 1 & 5 & 4.12 & 1.104 \\
\hline Handling customers feedback online & 28 & 2 & 5 & 4.10 & 0.810 \\
\hline On-line electronic brochures or buying guides & 28 & 3 & 5 & 4.02 & 0.550 \\
\hline Coordinating procurement with suppliers online & 28 & 3 & 5 & 3.91 & 0.842 \\
\hline Display company information on website & 28 & 2 & 5 & 3.91 & 1.065 \\
\hline Tracking incoming and outgoing goods delivery & 28 & 3 & 5 & 3.91 & 0.740 \\
\hline Allowing a customer to contact a sales office & 28 & 3 & 5 & 3.87 & 0.747 \\
\hline Provide product information to customers & 28 & 2 & 5 & 3.83 & 0.829 \\
\hline Online help-frequently asked questions & 28 & 3 & 5 & 3.81 & 0.563 \\
\hline Electronic data interchange (EDI) & 28 & 2 & 5 & 3.74 & 0.799 \\
\hline $\begin{array}{l}\text { display only a range of products that are } \\
\text { relevant to the particular customer }\end{array}$ & 100 & 3 & 5 & 3.72 & 0.587 \\
\hline Online application or registration & & & & & \\
\hline Online order entry and delivery & 100 & 2 & 5 & 3.67 & 0.726 \\
\hline Valid N (listwise) & 100 & 2 & 5 & 3.62 & 0.736 \\
\hline
\end{tabular}

Table 1 indicates that the business activities that were most undertaken by the selected businesses using telecommunication networks and/or the internet were online products updates, electronic fund transfer (EFT), online credit card processing, sharing information with competitors, making payments to suppliers online, coordinating procurement with suppliers online, handling customers' feedback online, and online electronic brochures or buying guides respectively. It can be seen that the mean values of these business activities were 4.37, 4.26, 4.20, $4.16,4.15,4.12,4.10$, and 4.02. These values are greater than the rater 4 (large extent) on the scale, 
which means that majority of the respondents were in agreement that telecommunication networks and the internet were used to undertake these businesses to a very large extent.

The other businesses activities were undertaken using telecommunication networks and the internet to a large extent, as indicated by the majority of the respondents.

It can be seen that online order entry and delivery were the least business activities that, according to the majority of the respondents, e- commerce was used to undertake. These business activities undertaken by the businesses were classified into advertising, customer support service, marketing, payment system, and order and delivery. Figure 1.4 below shows that the use of e-commerce, including telecommunication networks and the internet, by the businesses was most used to undertake payment systems, followed by marketing. Advertising was the least business activity to which e-commerce was used by the businesses.

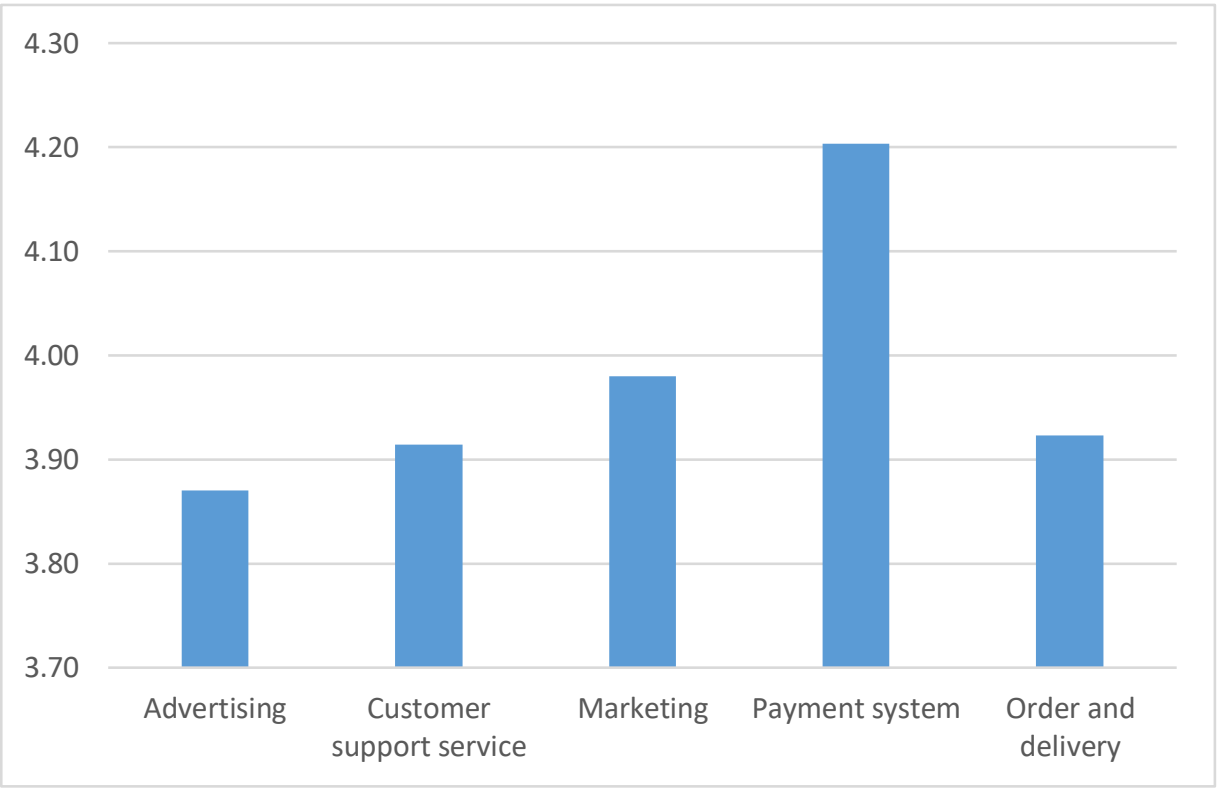

Figure 5. The Extent of Adoption and Usage of E-commerce in Specific Business Activities

Previous studies observed that due to the potential of e-commerce to improve efficiency and productivity, it had received significant attention by many businesses of all types in many countries, including developing countries [5, 38, 53]. Several studies done across developing countries in Africa, including [40, 5, $38,39,17]$, revealed that though generally, the extent of adoption and use of e-commerce among SMEs in these countries had not been rapid and massive due to several challenging factors, it had been improving over the years.

Iddris [17] studied e-commerce adoption and use by SMEs in Kumasi, Ghana, and found that many of these businesses had not fully adopted e-commerce solutions. The results of the study showed that SMEs online sales was virtually nil and that the most common e-commerce application was the use of e-mail for communication, and the main reason for having a website was to show basic information about product and services as well as contact information.

However, the data collected and analysed in this study with regard to the extent of adoption and use of e-commerce among SMWREs in Kumasi revealed that all the various types of businesses that participated in the study used ecommerce in various ways to undertake their business. The results indicate that, to a large extent, the businesses used telecommunication networks and the internet in several ways to undertake three categories of business activities: 1) advertising, 2) customer support service, and 3) marketing. 
These results relating to the nature and extent of adoption and usage of e-commerce in business thus confirm the observations and findings of previous studies due to the potential of ecommerce to improve efficiency and productivity, its adoption and application continue to receive growing significant attention by many businesses of all types in many countries including developing countries.

\section{Factors Influencing the Adoption and use of Electronic Business}

On a scale of 1 to 5 representing ' 1 - not at all, 2- very little, 3- some extent, 4- large extent and, 5- very large extent, the respondents were asked to indicate the extent to which the listed factors in Table 2 accounted for limited or low use of electronic business methods among them. Table 2 presents a summary of their feedback:

Table 2. Summary of the Factors Influencing the Adoption and Usage of e-commerce

\begin{tabular}{|l|l|l|l|l|l|}
\hline & N & Min & Max & Mean & $\begin{array}{l}\text { Std. } \\
\text { Deviation }\end{array}$ \\
\hline $\begin{array}{l}\text { E-commerce use is too low among the company's } \\
\text { customers }\end{array}$ & 28 & 2 & 5 & 3.88 & 0.935 \\
\hline Telecommunications services not dependable & 28 & 3 & 5 & 3.83 & 0.682 \\
\hline $\begin{array}{l}\text { The company has limited knowledge of the required e- } \\
\text { commerce technology }\end{array}$ & 28 & 2 & 5 & 3.79 & 0.782 \\
\hline Cost of computers and network technologies are too high & 28 & 1 & 5 & 3.74 & 1.041 \\
\hline $\begin{array}{l}\text { Company's concerns about legal issues, contracts and } \\
\text { liability }\end{array}$ & 28 & 1 & 5 & 3.59 & 0.900 \\
\hline Level of computerization is too low in the company & 28 & 2 & 5 & 3.57 & 0.967 \\
\hline $\begin{array}{l}\text { E-commerce use is too low among the company's } \\
\text { suppliers }\end{array}$ & 28 & 1 & 5 & 3.45 & 0.914 \\
\hline The company's concern about internet security & 28 & 2 & 5 & 3.44 & 0.795 \\
\hline $\begin{array}{l}\text { Company not convinced of the financial benefits of e- } \\
\text { commerce }\end{array}$ & 28 & 1 & 5 & 3.37 & 1.390 \\
\hline Valid N (listwise) & 28 & & & & \\
\hline
\end{tabular}

Table 2 shows that majority of the respondents indicated that the most influencing factor that determined their adoption and use of e-business was the businesses' observation that e-business use was low among their customers. This factor had a mean score of 3.88 , which is greater than the rater 3 and thus implies that, to a large extent, the majority of the businesses' adoption and use of e-commerce was determined by how much their customers used it.

The other factors that determined the businesses' extent of adoption and use of ebusiness to a large extent were: Telecommunications services not dependable (mean score 3.83); The company has limited knowledge of the required e-commerce technology (mean score 3.7); Cost of computers and network technologies are too high (mean score 3.74); Company's concerns about legal issues, contracts, and liability (mean score 3.59); Level of computerization is too low in the company(mean score 3.57); E-commerce use is too low among the company's suppliers (mean score 3.45); The company's concern about internet security (mean score 3.44); Company not convinced of the financial benefits of ecommerce (mean score 3.37).

Results from various empirical studies agree that most common factors influencing the extent of adoption and use by businesses across the globe including low use of e-commerce by Customers and Suppliers; concerns about 
security aspects; concerns about legal and liability aspects; high costs of development and computer and networking technologies commerce; limited knowledge of e-commerce models and methodologies; unconvinced of benefits to the company [42].

This study tested the extent to which these factors really influenced the adoption and use of e-business by SMEs in Kumasi. The results confirmed that, to a large extent, these factors practically influenced the businesses' decision to adopt and use e-commerce. It was realized that the most influencing factor, as indicated by the majority of the respondents, was the businesses' customer's low use of e-commerce, which means that there is little incentive for SMEs to engage e-commerce until their customers are also using it. This factor was respectively followed by telecommunications services not being dependable; the company has limited knowledge of the required e-commerce technology, cost of computers and network technologies are too high, the company's concerns about legal issues, contracts and liability, the level of computerization being very low in the company, e-commerce use being very low among the company's suppliers, the company's concern about internet security, company not convinced of the financial benefits of e-commerce.

\section{Impact of Electronic Business on Performance}

Finally, the study assessed the impact of electronic business on and the performance of the selected SMEs in Kumasi. Based on available operational, financial or accounting, and market data of the companies, the respondents were asked to indicate the extent to which the use of e-business increased the operational, financial, and market-based performance of the business over the years. Results of the descriptive statistics indicating the impact are as summarized in Table 3 below:

Table 3. Summary of the Impact of e-commerce on Business Performance

\begin{tabular}{|l|l|l|l|l|l|}
\hline & N & Minimum & Maximum & Mean & Std. Deviation \\
\hline Market value added & 100 & 3 & 5 & 3.93 & 0.477 \\
\hline Market share & 100 & 2 & 5 & 3.90 & 1.040 \\
\hline Annual return & 100 & 2 & 5 & 3.87 & 0.950 \\
\hline product/service quality & 100 & 2 & 5 & 3.87 & 0.747 \\
\hline Profitability & 100 & 3 & 5 & 3.85 & 0.539 \\
\hline Financial growth & 100 & 3 & 5 & 3.83 & 0.865 \\
\hline Leverage, liquidity and cash flow & 100 & 2 & 5 & 3.78 & 0.675 \\
\hline Marketing effectiveness & 100 & 3 & 5 & 3.71 & 0.591 \\
\hline Introduction of new products/services & 100 & 2 & 5 & 3.70 & 0.823 \\
\hline Customer satisfaction & 100 & 1 & 5 & 3.63 & 1.152 \\
\hline Efficiency & 100 & 3 & 5 & 3.40 & 0.620 \\
\hline Return to shareholders & 100 & 2 & 5 & 3.13 & 0.939 \\
\hline Valid N (listwise) & 100 & & & & \\
\hline
\end{tabular}

With regard to the impact of e-commerce on the performance of the businesses that participated in the study, it was discovered, as shown in Table 3 above, that market value-added recorded the highest mean score of 3.93, closely followed by market share with a mean score of 3.90. These values are greater than the rater 3 on the scale, which means that to a large extent, ebusiness impacted the market value and market share of the companies according to available operational, financial, or accounting and market data of the companies as indicated by the majority of the respondents. 
The majority of the respondents also indicated that e-business had made a significant impact on the operational, financial, and market-based performance of their businesses over the years with reference to the following performance indicators: annual return (mean score 3.87), product/service quality (mean score 3.87), profitability (mean score 3.85 ), financial growth (mean score 3.83), leverage, liquidity, and cash flow (mean score 3.78), marketing effectiveness (mean score 3.71), the introduction of new products/services (mean score 3.70), customer satisfaction (mean score 3.63), efficiency (mean score 3.40), and return to shareholders (mean score 3.13).

With regard to the benefits of e-commerce, these results of the study are in conformity with the observations and findings of previous studies, which generally found and agree that the benefits of e-commerce use to businesses include improved information exchange with customers/suppliers, improved customer service, expanded business reach, access to international markets, reducing costs, financial growth, leverage, liquidity, and cash flow, and marketing effectiveness $[4,3,41,40,5,62]$.

\section{Conclusion}

The three main objectives of the study were achieved through the survey. The results provide

\section{References}

[1]Zwass, V., 1996, Electronic Commerce: Structures and Issues, International Journal of Electronic Commerce, 1:1, 3-23, DOI: 10.1080/10864415.1996.11518273.

[2] Lai, P.C., 2017, The Literature Review of Technology Adoption Models and Theories for the Novelty Technology, Journal of Information Systems and Technology Management, 14(1), 21-38.

[3] Harrison, D.A., Mykytyn, P.P. and Rienenschneider, C.K., 1997, Executive Decisions About IT Adoption in Small Business: Theory and Empirical Tests, Information Systems Research, 8, 2, 171-195 evidence that different e-commerce applications are adopted and used by SMEs in Kumasi, including electronic marketing, electronic advertising, and electronic payment system, and that this use has over the years made significant impact on their organizational performance, which is measured by market-based performance, operational performance, and financial performance. Analysis of the results revealed that e-commerce adoption and usage had a positive and significant impact on the organizational performance of the SMEs that participated in the study.

However, several factors impede the more and effective use of e-commerce among these businesses. Key among these factors is the businesses' customer's low use of e-commerce, telecommunications services not dependable, the company has limited knowledge of the required e-commerce technology, cost of computers and network technologies are too high, and the company's concerns about legal issues, contracts and liability. Notwithstanding, due to the potential of e-business to improve efficiency, productivity, market value, and market share, its adoption and use will continue to increase and among SMEs in Kumasi till it is no longer an option.

[4] Iacovou, C.L., Benbasat, I., and Dexter, A.A., 1995, Electronic Data Interchange and Small Organisations: Adoption and Impact of Technology, MIS Quarterly, 19, 4, 465-485.

[5] Bondinuba, F.K., 2012, Exploring the challenges and barriers in accessing financial facilities by small and medium construction firms in Ghana. Civil and Environmental Research ISSN 2222-1719 (Paper) ISSN 2222-2863(online) Vol. 2, No.6.

[6] Kayanula, D. and Quartey, P. (2000). The policy environment for promoting small and medium-sized enterprises in Ghana and Malawi. Finance and Development Research Programme, Working Paper 
Series, Paper No 15. IDPM, University of Manchester.

[7] Aryeetey, E., 2010, Informal finance for private sector development in Africa. Economic Research Papers No. 41, The African Development Bank, Abidjan.

[8] Abor, J. and Biekpe N. (2006). Small Business Financing Initiatives in Ghana. Problems and Perspectives in Management, Volume 4, Issue 3.

[9] Abor, J. (2007). Capital structure and financing of SMEs: Empirical evidence from Ghana and South Africa. Dissertation presented for the Degree of Doctor of Philosophy at the University of Stellenbosch.

[10] Akorsu, P.K. and Agyapong, D. (2012). An alternative model for financing SMEs in Ghana. International Journal of Arts and Commerce Vol. 1 No. 5, October.

[11]Hinson, R., Sorensen, O., 2006, E-business and small Ghanaian exporters: Preliminary micro firm explorations in the light of a digital divide. Online Information Review, Vol. 30 Issue: 2, pp.116-138, doi:10.1108/14684520610659166.

[12]Hinson, R., and Boateng, R. (2007). Perceived Benefits and Management Commitment to EBusiness Usage in Selected Ghanaian Tourism Firms. EJISDC, Vol. 31, No. 5, pp 1-18.

[13] Saffu, K., Walker, J. and Hinson, R., 2008, Strategic Value and E-commerce Adoption: An Empirical Study of Small and Medium Enterprises (SMEs) in Ghana. 51st ICSB World Conference, Melbourne, Australia, 18th-21st June 2006: Refereed Conference Proceedings.

[14]Boateng, R., Heeks, R., Alemayehu Molla, A, and Hinson, R., 2011, Advancing E-commerce Beyond Readiness in a Developing Country: Experiences of Ghanaian Firms. Journal of Electronic Commerce in Organizations, 9(1), 1-16.

[15] Asare, D., Gopolang, B., Mogotlhwane, O., 2012. Challenges facing SMEs in the adoption of ICT in B2B and B2C E-commerce: A comparative case study of Botswana and Ghana. International Journal of Commerce and Management, Vol. 22 Issue: 4, pp.272-285.

[16] Iddris, F., 2012, Adoption of E-Commerce Solutions in Small and Medium-Sized Enterprises in
Ghana. European Journal of Business and Management Vol. 4, No.10, www.iiste.org. [17] Awiagah, R., Kang, J., and Jay Ick Lim, J.I., 2015, Factors affecting e-commerce adoption among SMEs in Ghana Ministry of Trade and Industry, Ghana Information Development 1-22. DOI: $10.1177 / 0266666915571427$.

[18] Okoli, C., \& Mbarika, V. A. W., 2003, A Framework for Assessing E-Commerce in SubSaharan Africa. Journal of Global Information Technology Management, 6(3), 44-66.

[19]Rogers, E.W, Wright, P.M., 1998, Measuring Organizational Performance in Strategic Human Resource Management: Looking Beyond the Lamppost. CAHRS Working Paper Series, p. 135.

[20] Garcia-Murillo, M., 2004, Institution and adoption of electronic commerce in Mexico, Electronic Commerce Research Journal, Vol. 4 No. 3, pp. 201-19.

[21]Hawk, S., 2004, A comparison of B2C ecommerce in developing countries, Electronic Commerce Research, Vol. 4, pp. 181-99.

[22] Kauffman, J., and Walden, E.A., 2001, Economic and electronic commerce: survey and direction for research, International Journal of Electronic Commerce, Vol. 5 No. 4, pp. 5-116.

[23] Combs, J.G.T, Crook, R, Christopher, L.S., 2005, The Dimensionality of Organizational Performance and its Implications for Strategic Management Research, in Professor David Ketchen and Professor Don Bergh (ed.) Research Methodology in Strategy and Management (Research Methodology in Strategy and Management, Vol. 2), Emerald Group Publishing Limited, pp. 259-286.

[24] Brealey, R.A., Myers, S.C, Marcus A.J., 2001, Fundamentals of Corporate Finance (3rd edn), New York: McGraw-Hill.

[25] Helfert, E.A., 1994, Techniques of Financial Analysis (8th edn), Boston, MA: Irwin.

[26] Higgins, R.C., 1995, Analysis for Financial Management (4th edn), Boston, MA: Irwin.

[27] Rose, G. and Straub, D.W., 2001, The effect of download time on consumer attitude towards the 285 e-service retails. E-service Journal, No. 1, pp. 56-76. [28] Wat, F.K.T., Ngai, E.W.T. and Chang, T.C.E., 2005, Potential risks to e-commerce development 
using exploratory factor analysis. International Journal of Services Technology \& Management, Vol. 6 No. 1, p. 1.

[29]Boateng, R., Heeks, R., Alemayehu Molla, A, and Hinson, R. (2011). Advancing E-commerce Beyond Readiness in a Developing Country: Experiences of Ghanaian Firms. Journal of Electronic Commerce in Organizations, 9(1), 1-16.

[30] Molla, A., \& Licker, P. S., 2005, E-Commerce Adoption in Developing Countries: A Model and Instrument. Information \& Management, 42(6), 877899. doi:10.1016/j.im.2004.09.002.

[31]Dada, D., 2006, E-readiness for Developing Countries, Moving the Focus from the Environment to the Users. The Electronic Journal of Information Systems in Developing Countries, 27(6), 1-14.

[32] De`elak, Z., Sternad, S., \& Bobek, S., 2006, Comparative Analysis of E-Business Implementation Critical Success Factors. Organizacija, 39, 169-175. [33]Lai, F., Dahui, L., Wang, J., \& Hutchinson, J., 2006, An Empirical Investigation of the Effects of EReadiness Factors on E-Business Adoption in China's International Trading Industry. International Journal of Electronic Business, 4(3-4), 320-339. doi:10.1504/IJEB.2006.010869.

[34] Tan, J., Tyler, K., \& Manica, A., 2007, Businessto-business adoption of e-Commerce in China. Information \& Management, 44(3), 332-351. doi:10.1016/j. im.2007.04.001.

[35]Dos-Santos, B. L., \& Peffers, K.,1998, Competitor and Vendor Influence on the Adoption of Innovative Applications in Electronic Commerce. Information \& Management, 34(3), 175-184. doi:10.1016/S0378- 7206(98)00053-6.

[36] Moodley, S., 2002, E-business in South African apparel sector: A utopian vision of efficiency? The Developing Economics, March, pp. 67-100.

[37] Maswera, T., Dawson, R., and Edwards, J., 2006, E-commerce adoption of travel and tourism organisations in South Africa, Kenya, Zimbabwe, and Uganda. Telematics and Informatics 25 (2008) 187200.

[38] Boateng, R., \& Hinson, R., 2008, Information Systems Development: Where does knowledge lie and how does learning occur? Development and
Learning in Organisations, 22(3), 18-20. doi:10.1108/14777280810861785.

[39] Cloete, E., Courtney, S., \& Fintz, J., 2002, Small Business' Acceptance and Adoption of e-Commerce in the Western-Cape Province of South Africa. The Electronic Journal of Information Systems in Developing Countries, 10(4), 1-13.

[40] Poon, S. Swatman, P.M.C, 1995, The Internet for small businesses: An enabling infrastructure for competitiveness. Paper presented at the Fifth Internet Society Conference, Hawaii, USA.

[41]Courtney, S. and Fintz, J., 2001, Small Businesses' Acceptance and Adoption of eCommerce in the Western-Cape Province of SouthAfrica, Empirical Research Project, Department of Information Systems, UCT.

[42] Kirby, D. and Turner, M., 1993, IT and the Small Retail Business, International Journal of Retail and Distribution Management, 21, 7, 20-27.

[43] Julien, P.A., and Raymond, L., 1994, Factors of New Technology Adoption in the Retail Sector. Entrepreneurship: Theory and Practice, 18, 5, 79-90. [44] Akkeren, J. and Cavaye, A., 1999, Factors Affecting the Adoption of E-commerce Technologies by Small Business in Australia - An Empirical Study. http://www.acs.org.au/act/events/io1999/akkern.htm 1.

[45] Thong, J. and Yap, C.S., 1995, CEO Characteristics, Organisational Characteristics, and Information Technology Adoption in Small Business, Omega, 23, 4, 429-442.

[46] Agrawal, V., Arjona, L. D. and Lemmens, R., 2001, E-performance: The Path to Rational Exuberance, The McKinsey Quarterly, No. 1, 30-43. [47]Castelman, T. and Cavill, M., 2001, Voices of Experience: Developing Export Capability Through Electronic Commerce in Australian SME's, Proceedings of the 14th Bled Electronic Commerce Conference.

[48]Davies, S., 2002, South African SME's and Internet Based Electronic Business, Empirical Research Project, Department of Information Systems, UCT.

[49]Wilde, W.D., and Swatman, P.A., 2000, Studying Telecommunication Enhanced 
Communities: An Economic Lens. Deakin University, School of Management.

[50] Walton, L.W. and Miller, L.G., 1995, Moving Toward IS Theory Development: A Framework of Technology Adoption Within Channels, Journal of Business Logistics, 16, 2, 117-135.

[51] Olatokun, W. and Kebonye, M., 2010, Ecommerce technology adoption by SMEs in Botswana", International Journal of Emerging Technology and Society, Vol. 8 No. 1, pp. 42-56.

[52] Lawrance, J.E. and Tar, U.A., 2010, Barriers to e-commerce in developing countries. Information, Society and Justice, Vol. 3 No. 1, pp. 23-35.

[53]Frempong, G., \& Stark, C., 2005, Ghana. In A. Gillwald (Ed.) Towards an African e-Index: Household and Individual ICT Access and Usage Across 10 African Countries. Retrieved from http://www.researchictafrica.net.

[54] Awiagah, R., Kang, J., and Jay Ick Lim, J.I., 2015, Factors affecting e-commerce adoption among
SMEs in Ghana Ministry of Trade and Industry, Ghana Information Development 1-22. DOI: $10.1177 / 0266666915571427$.

[55] Rovenpor, J., 2003, Explaining the e-commerce shakeout: why did so many internet-based business fail? E-Service Journal, Vol. 31 No. 1, pp. 53-77.

[56]Zikmund, W.G. (2003). Business Research Method, (7th edn.). Cengage Learning, India.

[57] Yin, R. K., 2003, Case Study Research: Design and Methods (3rd ed.). Newbury Park, CA: Sage.

[58] Creswell, J.W. and Plano, V.L. (2009). Designing and Conducting Mixed Methods Research. SAGE.

[59] Marczyk G., DeMatteo D. \& Festiner D., (2005). Essential of Research Design and Methodology: John Wiley \& Sons, New Delhi.

[60] Saunders, M., Lewis, P. \& Thornhill, A. (2009). Research Methods for Business Students (5th edn). Edinburgh: Prentice Hall. 